\title{
FROM BLOCKHOUSE TO HOG HOUSE: THE HISTORICAL DENDROARCHAEOLOGY OF THE SWAGGERTY BLOCKHOUSE, COCKE COUNTY, TENNESSEE, U.S.A.
}

\author{
DAVID F. MANN ${ }^{1}$, HENRI D. GRISSINO-MAYER ${ }^{1 *}$, CHARLES H. FAULKNER ${ }^{2}$, and JOHN B. REHDER ${ }^{3}$ \\ ${ }^{1}$ Laboratory of Tree-Ring Science, Department of Geography, The University of Tennessee, Knoxville, \\ Tennessee 37996, USA \\ ${ }^{2}$ Department of Anthropology, The University of Tennessee, Knoxville, Tennessee 37996, USA \\ ${ }^{3}$ Department of Geography, The University of Tennessee, Knoxville, Tennessee 37996, USA
}

\begin{abstract}
The Swaggerty Blockhouse has historical and cultural significance for Tennessee because it is believed to be the only remaining $18^{\text {th }}$ Century blockhouse in the state. We incorporated analyses of artifacts obtained from archaeological excavations coupled with tree-ring dating techniques to determine the possible year of construction of the structure. A nearby reference tree-ring chronology from Norris Dam anchored the Swaggerty Blockhouse tree-ring chronology from 1674 to 1859 . The assemblages of artifacts (nails, ceramics, and window glass) recovered from the site corroborated the construction date and provided a clear understanding of the structure's use as a barn for storage and hog processing. Based on our analyses, the historic Swaggerty "Blockhouse," originally believed to have been built by James Swaggerty in 1787, is instead a small cantilever barn built by Jacob Stephens in 1860 and used for hog farming.
\end{abstract}

Keywords: Dendrochronology, Quercus, construction date, ceramic dates, nail dates, blockhouse.

\section{INTRODUCTION}

The excavation of wood remains and the sampling of structural timbers have allowed archaeologists and dendrochronologists to extend tree-ring chronologies further back in time and provide a better understanding of human history and the environment in which human cultures lived (Dean 1978; Euler et al. 1979; Stahle et al. 1998; Druckenbrod et al. 2003). In recent years, site management agencies and historical societies in the eastern U.S. are increasingly requiring the verification of construction dates of historically meaningful structures to ensure their authenticity, and tree-ring dating provides a means for doing so with annual (and sometimes subannual) precision (Stahle 1979; Jurney 1986; Hilliard and Thomson 1998; Wight and Grissino-Mayer 2004; GrissinoMayer and van de Gevel, 2007). Sampling often requires that cores be extracted from as many logs

\footnotetext{
* Corresponding author: grissino@utk.edu; Fax 865974-6029; Telephone 865-974-6029
}

in the structure as possible, and at least two cores should be extracted from each log. Furthermore, caution must be exercised because logs can be replaced after the original construction date (resulting in a date for that log later than the year of construction) or reused from previous on-site or off-site structures (resulting in a date for that log that is earlier than the year of construction).

The focus of this dendroarchaeological study, the Swaggerty Blockhouse (Figure 1), is a threestory, pen-over-pen log structure believed to have been built in 1787 by James Swaggerty. Blockhouses were defensive structures built for families and volunteer militias that protected early settlements (Jordan 1985), most notably from the Cherokee tribes who greatly objected to increasing settlement by Euro-Americans on their traditional lands. The blockhouse is located on Clear Creek, along U.S. Highway 321, northeast of Newport, in Cocke County, Tennessee (Figure 2). The structure was added to the National Register of Historic Places in 1973, and lists its "Period of 


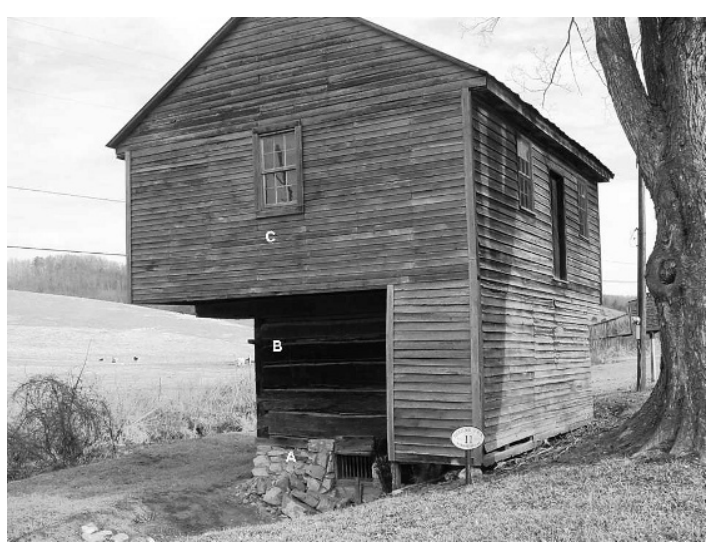

Figure 1. The Swaggerty Blockhouse, Cocke County, Tennessee, showing the first level (A), the original oak logs sampled in this study on the second level (B), and the cantilevered third level (C). Clapboard siding currently covers much of the structure (photograph by David F. Mann).

Significance" as 1750-1799 (National Register of Historic Places 2007). Inspections by the Tennessee Historical Commission, however, raised doubts concerning the authenticity of the late $18^{\text {th }}$ Century date of construction for this blockhouse. The purpose of this study is to (1) analyze log building techniques and diagnostic features in the Swaggerty Blockhouse to help determine its purpose, (2) establish the cutting dates of the logs to date the year(s) of construction of the building, and (3) establish a collection of artifacts that will provide insights into the lifeways of past residents and corroborate the possible purpose of the structure.

\section{Ownership History}

Frederick Swaggerty was born in 1725 at Niederingelheim, Germany. In 1785, Swaggerty established residency in Greene County, Tennessee, and later settled in the "Dutch Valley" of present-day Cocke County with his wife, Elizabeth, and nine children. There is no record of Frederick Swaggerty again until 1824, when James Swaggerty was deeded 114 acres of land once owned by his father, Frederick. In the 1839 tax list for Cocke County, James Swaggerty was listed as having 500 acres of land and three slaves. On 22 March 1850, James Swaggerty sold 114 acres to Jacob Stephens, which included the original

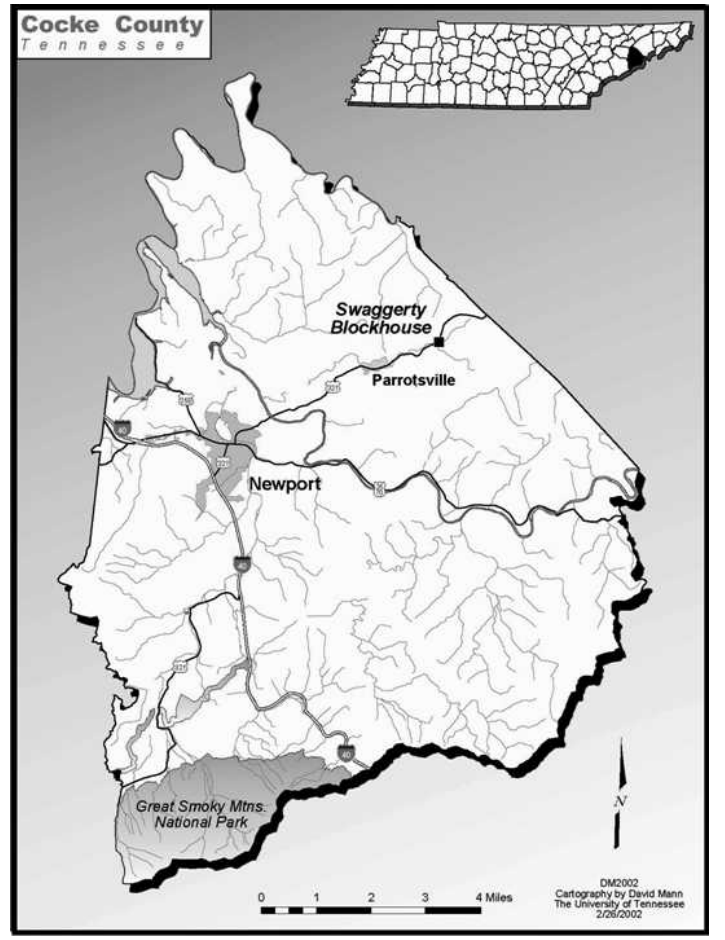

Figure 2. Cocke County, Tennessee, showing the location of the Swaggerty Blockhouse in the eastern part of the county.

farmstead settled and built by Frederick Swaggerty (Houston 1984).

Jacob Stephens is listed on the 1860 Head of Household census for Cocke County, then 57 years old, living with his wife and nine children. His occupation is listed as a farmer with 120 acres of improved land and 50 acres of unimproved land. His farm was valued at $\$ 4,500$ with $\$ 200$ of farm machinery and livestock valued at $\$ 1060$ (U.S. Census Office 1860). The $1870 \mathrm{Head}$ of Household census showed that the value of Stephens' farm dropped significantly in the post Civil War era to approximately $\$ 3,000$ (U.S. Census Office 1870). Jacob Stephens died on 12 June 1879 and the farm was left to his four children. S.A. Burnett, a son-in-law, became owner of the farm and then passed it on to his two children, O.L. Burnett and his sister S.B. Neas, the grandchildren of Jacob Stephens. T.J. Gillespie bought 187 acres (including the original 114 acres) and the farm from O.L. Burnett on 4 January 1921. Upon his death, T.J. Gillespie deeded Gay Gillespie, his grandson, the farm on 
6 January 1923 (Gay Gillespie, personal communication).

\section{Structure of the Swaggerty Blockhouse}

The Swaggerty Blockhouse consists of three levels. The first level, from which a natural spring flows, is constructed of large stones, mainly limestone and mortar. The use of stone in the area of the Tennessee Valley remains limited to outbuildings, chimney foundations, and foundations of $\log$ and frame buildings (Kniffen 1990). The stones located in the springhouse walls of the Swaggerty Blockhouse contain mortar made from leached limestone, hardwood ash, and red clay. This level serves as the foundation for the second level and appears to have been used for storage as a springhouse.

The second level of the structure measures 16 feet square $\left(23.8 \mathrm{~m}^{2}\right)$ and is constructed of heavy oak (Quercus spp.) timbers all hewn on two sides. Evidence of the process of scoring can still be seen on the timbers. The lack of care taken by the builder in maintaining a direct plane with the chalk line is clear because most of the timbers contain deep gouges made by the broadax when removing the sections between the scoring marks. The corner timbering is joined with half dovetail notching (Glassie 1963; Kniffen and Glassie 1966; Kniffen 1969). Unlike the hewing of the timbers, the half dovetail corner notching is extremely precise. The result is a second level made up of heavy oak timbers that are structurally sound and allows for sufficient support of the massive loft floor timbers. The presence of wooden pegs and shelving in this level indicates previous use as a storage area.

The third level measures 21 feet square $\left(41 \mathrm{~m}^{2}\right)$ and is constructed of tulip poplar (Liriodendron tulipifera L.) logs joined by mortise and tenon (Benson 1988) and cantilevers four feet $(1.2 \mathrm{~m})$ over the second level on all sides of the structure. The framing system in the upper loft of the Swaggerty Blockhouse is classified as a modified queen post (Moffett and Wodehouse 1993). Single six-over-six pane windows face to the north, west, and south, and a double set of windows faces east. The exterior of the upper loft walls are covered with lapped horizontal clapboard siding. Entrance to the upper loft is gained through an exterior set of stairs located on the north side of the structure. A front-facing door opens to the east toward an area believed to have been a wagon road.

\section{METHODS}

\section{Dendrochronological Methods}

Timbers in the Swaggerty Blockhouse were first examined to determine the species type and evaluate the feasibility of sampling and dating via dendrochronology. Although tree rings from tulip poplar trees can be dated using dendrochronology (Barlar 2000; Lafon 2004), the species forms very faint rings that are not easily discerned, even after sanding to a high polish. We therefore concentrated our sampling on the second level where oak logs were used exclusively, but did collect cores from a few selected tulip poplar logs on the third level. We also visually examined individual structural timbers and their placements to ensure that those sampled were not reused timbers or timbers of later insertions and repairs.

We inspected the distal and basal ends of each timber for (1) the presence of intact bark, (2) beetle galleries on the log surface, or (3) surface patina (i.e. a "sheen") or smoothness that develops on logs once the bark has been stripped off purposely or sloughed off naturally over time (Nash 1999). These properties all indicate that the last-formed outermost ring (and therefore the cutting date) is likely to be intact. Timbers within the structure were then numbered according to position from the uppermost timber to the lower sill timber. We sampled the logs in situ with an increment borer that extracted small dowel-sized cores measuring $5 \mathrm{~mm}$ in diameter. Care was taken to ensure that all outer rings remained intact because these rings are usually located in the softest portion of the timbers (i.e. the sapwood) and are susceptible to decay and insect damage. Once extracted, the cores were immediately stabilized by gluing in core mounts to prevent breakage of the old wood. Each core was appropriately labeled according to its location on the log, and the log's location within the structure (e.g. "SWG01AE" = Swaggerty, log 01 (lowest $\log$ ), core A, eastern side of building). 
In the laboratory, cores were allowed to airdry, then sanded using a progression of grit sizes beginning with ANSI 80-grit $(177-210 \mu \mathrm{m})$ and ending with ANSI 400-grit $(20.6-23.6 \mu \mathrm{m})$ to ensure the cellular features of the individual tree rings were visible under standard $10 \times$ magnification (Orvis and Grissino-Mayer 2002). The treering patterns from all cores were crossdated first using skeleton plots (Stokes and Smiley 1968; Swetnam et al. 1985) by comparing the patterns to those found on a reference skeleton plot created from white oak trees (Quercus alba L.) growing near Norris Dam, Tennessee (Duvick 1981), located 62 miles $(100 \mathrm{~km})$ west-northwest from the Swaggerty Blockhouse. Both Norris Dam and the Swaggerty Blockhouse are located in the Ridge and Valley physiographic region of eastern Tennessee, which should result in similar tree-ring patterns caused by similar climate across the region to which the trees respond.

Once a convincing graphical match was found, the inner and outer dates were recorded as well as the outermost ring type (Bannister 1962; Nash 1999; Grissino-Mayer and van de Gevel 2007):

$\mathrm{B}$ : bark is present, indicating the outer ring is fully intact (certainly a cutting date);

$r$ : outermost ring is continuous and intact around a smooth (patina) surface, but no bark is present (considered a cutting date); $\mathrm{v}$ : the date is within a few years of the cutting date, based on presence of sapwood;

vv: impossible to determine how far the outer ring is from the true outer surface (no sapwood and rings in the heartwood are likely missing).

All tree rings were then measured to 0.001 $\mathrm{mm}$ accuracy using a Velmex micrometer and recorded with the MEASURE J2X measurement program. Measurements were then processed through the computer program COFECHA to check the visual and graphical crossdating. COFECHA used segmented time series correlation techniques to test 40-year segments from one series with the same 40-year segment from a chronology created from all remaining series (Holmes 1983; Grissino-Mayer 2001). The analysis was repeated for the next 40 -year segment lagged by 20 years until all segments in the core being tested were analyzed. Correlation coefficients for successful crossdating of 40-year segments had to be statistically significant ( $\mathrm{p}<0.01, \mathrm{r} \geq 0.37$ ), but often significance was much lower (and correlation coefficients correspondingly much higher) for segments that were correctly crossdated ( $p<$ $0.005, \mathrm{r} \geq 0.40$ ).

A composite master chronology was then developed by first dividing the actual measurement value for any particular year by the predicted value obtained from a detrending routine using the program CRONOL (Cook 1985) to develop an index of tree growth for that particular year. Indices for each year were then averaged across all series to develop the final master chronology for the Swaggerty Blockhouse. In all subsequent analyses, we used the RESIDUAL (RES) chronology created by CRONOL. The master chronology was then tested against the reference chronology for Norris Dam, again using COFECHA by entering the Swaggerty Blockhouse chronology initially as an undated series, which would confirm (or refute) our graphical crossdating. The crossdating of the tree rings from the Swaggerty Blockhouse had to be convincing both graphically and statistically (Grissino-Mayer 2001).

\section{Archaeological Methods}

The area of testing and examination for archaeological artifacts measured approximately $200 \times 75$ feet $(61 \times 22.9 \mathrm{~m})$ and extended from the blockhouse north to an access road, and is bordered by Clear Creek to the west and U.S. Highway 321 to the east. The soil core testing used a $36 \times 1$-inch $(91.4 \times 2.5 \mathrm{~cm})$ soil sampler to identify areas of possible soil disturbance, and to help locate such anomalies as brick, stone foundations, ditches, postholes, and trash pits. The soil surface was visually examined to locate and develop a collection of artifacts that were readily visible at the surface. The site and building were also visually inspected to locate and identify important diagnostic structural artifacts, such as nails and window glass. The area adjacent to the blockhouse 
was then gridded using a six-foot $(1.83-\mathrm{m})$ oncenter grid system. The grid was established using a transit surveying system utilizing the east face of the blockhouse as the north-south axis, or site meridian (Hester et al. 1975). The transit system was also used to create an alpha datum point that was used to establish all measurements within the grid.

Forty-two shovel test pits were excavated on all sides of the structure. Shovel testing involved the removal of a one-foot $(30-\mathrm{cm})$ diameter section of turf exposing the upper section of humus. Subsequent levels were then removed with a shovel or trowel and all soil color changes and changes in soil texture were recorded. The depth of each shovel test depended on the stratigraphy of the underlying strata and on living tree roots that were abundant on the east side of the structure. All soil removed was passed through 0.25 -inch $(0.64-\mathrm{cm})$ mesh hardware cloth onto a two-foot square screen. All artifacts recovered were recorded on standard shovel testing field forms, bagged and labeled according to accepted practice, and boxed for transport. Test pits were then back-filled with screened soil and the turf replaced.

The artifact assemblage was processed at the Historical Archaeology Laboratory in the Department of Anthropology at the University of Tennessee. Artifacts were classified into nine groups: kitchen storage, kitchen service, pharmaceutical bottles, farm tools, architecture nails, bone fragments, clothing buttons, stable and barn, and wood remains. Each artifact was then washed, numbered, measured, bagged in clear plastic, and a detailed artifact form was filled out.

Ceramic types and styles are diagnostic of the range of years in which they were created (Quimby 1973; Miller 1980), but have only sparingly been used to help date sites in eastern Tennessee (Polhemus 1977; Faulkner 1984) and North Carolina (Stine 2005; Grissino-Mayer and Henderson 2006). We calculated the mean ceramic date by taking the sum of the artifacts making up the median date for the manufacturing date range for each ceramic sherd and then multiplying by the total frequency, or the count in any given interval, and dividing the sum by the number of sherds in the total population (South 1977).
Nails were examined for manufacturing and condition. The manufacturing date range for each nail was determined using established diagnostic physical features (Young 1994; Wells 1998). Handwrought, "rosehead" nails indicate pre-1790 construction, "square-head" nails indicate construction between 1790 and 1830, headless "machinecut" nails indicate 1830 to 1890 construction, and wire nails indicate post-1890 construction.

Moir (1987) developed a classification scheme that uses a simple formula to determine a range of years for glass of a particular thickness, and is particularly useful for evaluating 19th Century glass. To determine the mean glass date, the thickness of each window glass sherd was first measured using calibers. The measurement value was then multiplied by 84.22 and the product added to 1712.7 to derive a date of manufacture for each glass sherd. Taking the sum of the assigned dates and dividing by the total population developed the mean glass date.

\section{RESULTS}

\section{Dendrochronological Dating}

We extracted 30 cores from the oak timbers on the second level of the structure. Of these, eight series were too short (12 to 62 years) to crossdate accurately with the Norris Dam reference chronology, nor did these eight series demonstrate any crossdating among themselves when entered into COFECHA as undated series (Grissino-Mayer 2001). The 22 series that crossdated showed strong internal dating among the series (Table 1), have an average series length of 109 years (range: 53 to 187 years), an average mean sensitivity of 0.22 (range: 0.17 to 0.36 ), and an average interseries correlation of 0.55 (range: 0.33 to 0.75 ). Of 11740 -year segments tested by COFECHA, 11 were flagged as being possibly misdated. Careful re-inspection revealed these segments to be dated correctly, as nearly all the flagged segments (9 of 11) occurred in the beginning or ending segments where crossdating is often weakest because of juvenile growth or distorted rings in the sapwood caused by decay.

The RES chronology created from the 22 series showed statistically significant crossdating with the RES chronology created for the Norris 


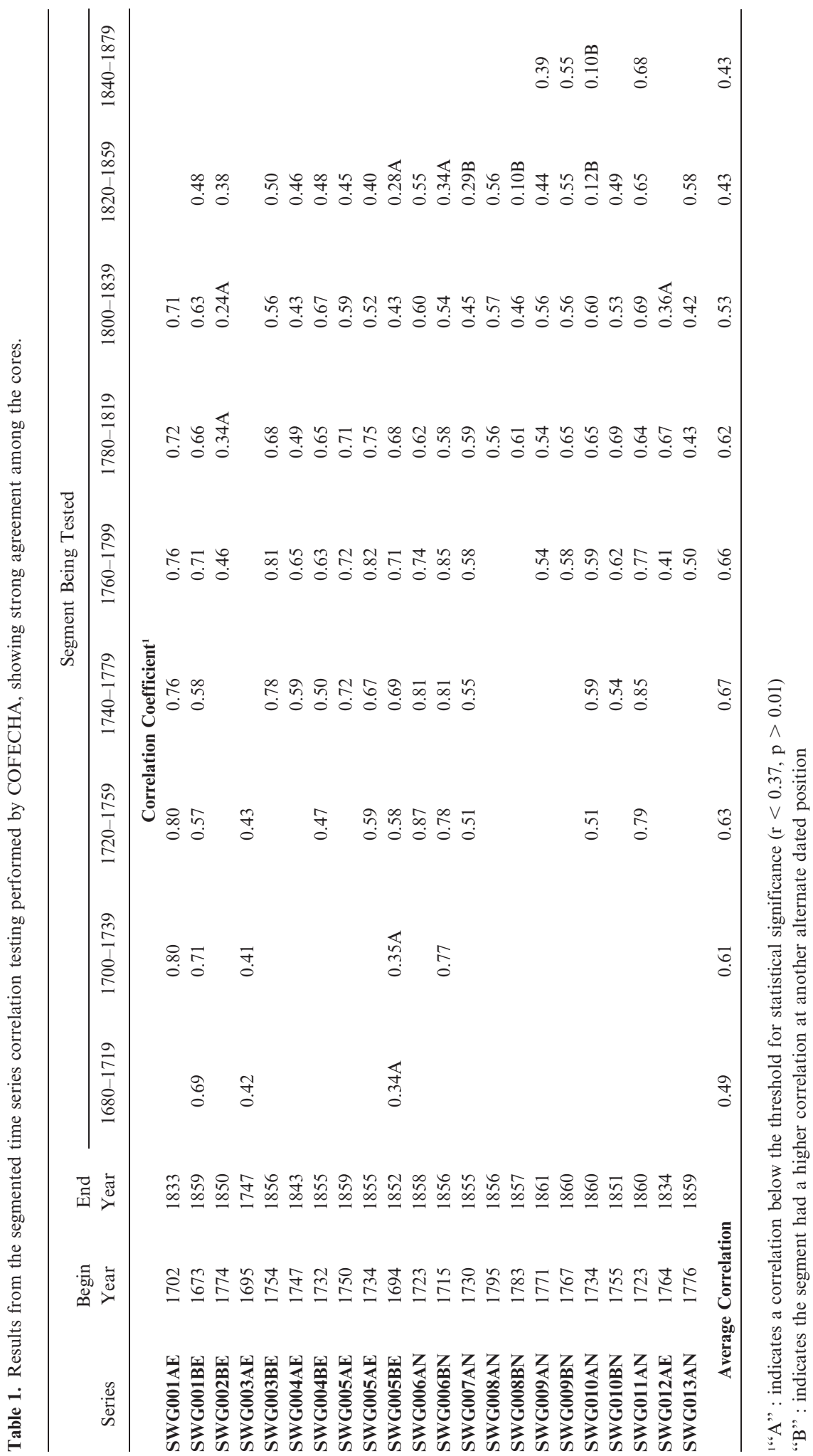




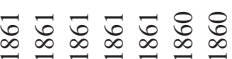

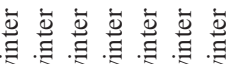

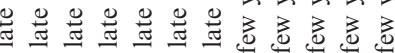

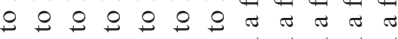

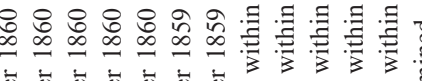

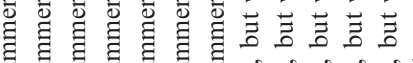

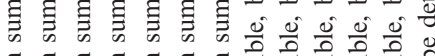

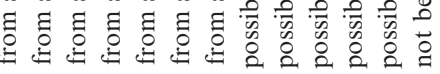

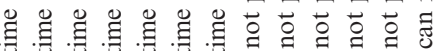

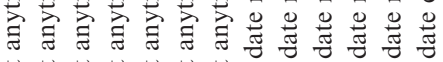

言言言言言言言

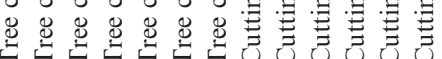
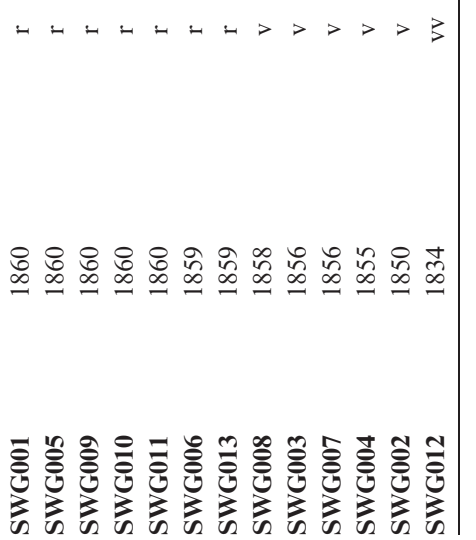

Dam white oak reference chronology $(\mathrm{r}=0.47, \mathrm{t}$ $=7.2, \mathrm{n}=185 \mathrm{yrs}, \mathrm{p}<0.0001)$ and a graphical match was convincing as well (Figure 3). To ensure accurate crossdating, we tested the Swaggerty RES chronology against the RES chronology for another regional white oak chronology, KY003 (spanning 1663 to 1982), located at the Lilley Cornett Tract in southeastern Kentucky (Cook 1983). We found a statistically significant correlation between the Swaggerty and Lilley Cornett RES chronologies (again, $\mathrm{r}=0.47, \mathrm{t}=$ $7.2, \mathrm{n}=185 \mathrm{yrs}, \mathrm{p}<0.0001)$, verifying the accuracy of crossdating. The Swaggerty master chronology is anchored firmly from 1673 to 1859 .

The 22 series represent 13 logs. Of these, the year of cutting could be determined for seven logs, while five logs provided near-cutting dates based on the presence of sapwood. One log, representing a core taken from one of the cantilever beams on the structure, had an outermost ring (1834) that was far from the true cutting date because the beam had been squared, as required, during construction. Five of the seven logs with definitive cutting dates were likely felled sometime between the summer of 1860 and the late winter of 1861 . These logs had an outermost ring that formed in 1860 , but we could not determine with confidence if this ring had completed formation before felling, and it was subsequently not measured. Two of the seven logs had an outermost ring that formed in 1859 , but again we could not determine if this ring was complete, and again it was not measured. The two logs could have been felled between late summer of 1859 and late winter of 1860 . These seven logs potentially could all have been cut sometime in 1860 . The five logs with near-cutting dates also support the 1860 construction. These logs had outermost rings of 1850, 1855, 1856, 1856 , and 1858 , but the decayed sapwood prevented accurate determination of the true cutting dates. Surprisingly, one measurement series taken from a tulip poplar log, SWG013, had rings that were very clear and their measurements crossdated significantly and with confidence with the series taken from the remaining 12 oak logs. This series also contained the longest sequence of tulip poplar tree rings (84) that we extracted from the logs on the third level of the structure. 


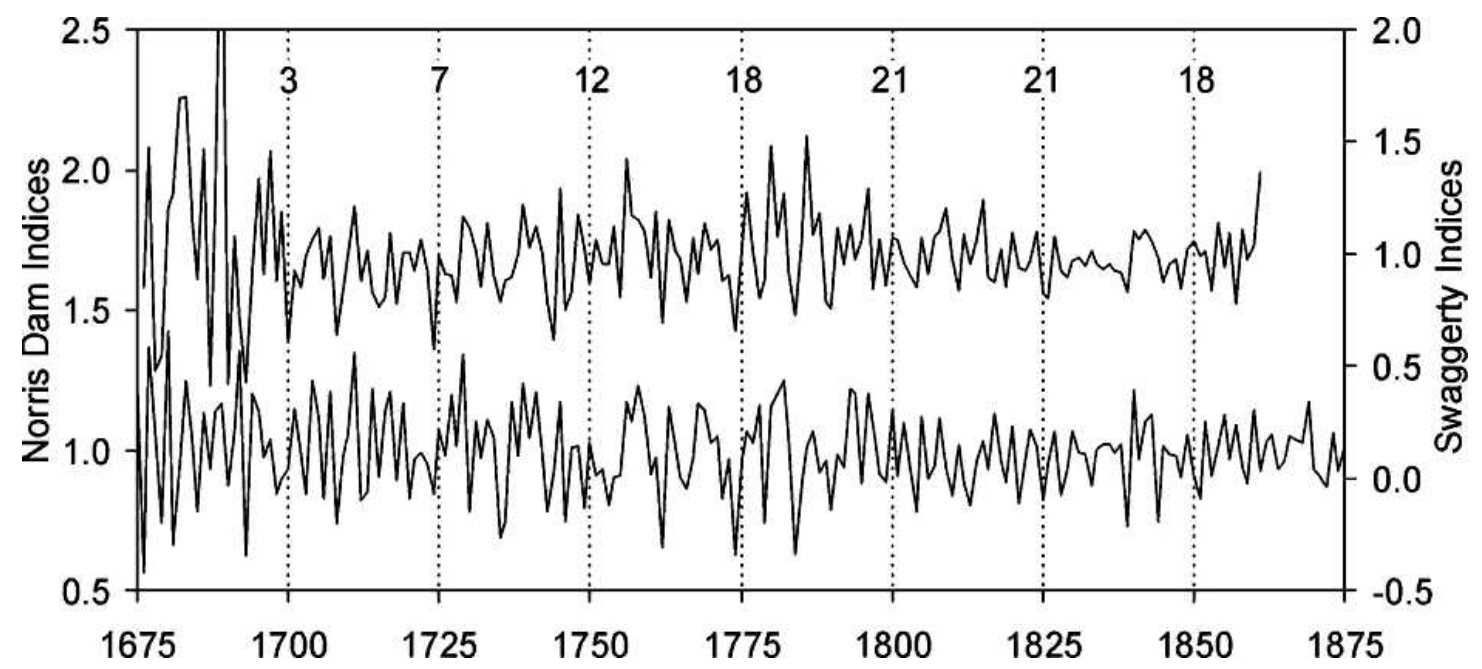

Figure 3. The Swaggerty RES master chronology (top) plotted against the Norris Dam RES master chronology (bottom), showing the high level of correspondence between the two chronologies $(r=0.47, t=7.2, n=185 \mathrm{yrs}, \mathrm{p}<0.0001)$. Sample depth (number of cores) is given across the top.

\section{Historical Archaeology}

Excavation of the shovel test pits on the south side of the structure resulted in the discovery of an older crushed limestone roadbed that ran along the east side of the blockhouse. This roadbed also ran directly under the door, which opened to the upper story of the structure. As testing moved more to the north and northeast side of the structure, we recovered faunal remains that included a hog tusk found in moderately dispersed layers of ash approximately 0.5 feet $(15 \mathrm{~cm})$ in thickness. The western side of the structure yielded the largest number of artifacts (46) and also a high amount of ash deposits. Faunal remains recovered included a mediumsized anklebone identified as swine. On the west side of the structure, we again uncovered a thick ash layer (up to 1.0 feet $(30 \mathrm{~cm})$ in thickness) and collected twelve ash specimens for further examination. Under $10 \times$ magnification, the small charred remains were identified as coming from hardwood tree species.

Kitchen service (which included a large portion of modern soda and beer bottles) made up $42 \%$ of the artifact collection, whereas the wood fragment group made up $24 \%$ of the collection. Neither group, however, aided in providing a maximum age of the structure.
Kitchen storage items made up $14 \%$ of the artifact collection and were excavated exclusively on the northern and western areas of the site. The assemblage included sherds from a salt-glazed coarse stoneware jar (1780-1900), a slip glazed coarse stoneware crock (1800-1900), a Bristolglazed coarse stoneware jar (1880-1900), a leadglazed redware jar (1800-1850), a plain whiteware cup (1830-1900), a salt-glazed coarse stoneware jar (1780-1900), and an alkaline-glazed coarse stoneware jar (1780-1900). The mean ceramic date of the assemblage was the year 1852 .

The nail assemblage ( 24 nails) was divided into two distinctive nail groups consisting of fully machine cut nails and wire nails. Fully machinecut nails with a date range for the east Tennessee region of $1830-1890$ made up $75 \%$ of the nail collection, while wire nails (date range of 1890 to the present) made up the remaining $25 \%$. The nail assemblage strongly indicates construction of the blockhouse in the early to mid-1800s. Had the structure been built in the 1780s as historically documented, hand-wrought (i.e. "rosehead") nails with dates of manufacture prior to 1790 (Wells 1998) should have been recovered from the site.

Thirty-six window glass fragments were recovered from both the surface collection and test pits. The assemblage of window glass was divided into 20 -year segments with $17 \%$ of the 
total dating from 1820 to $1840,19 \%$ from 1841 to $1860,28 \%$ from 1861 to $1880,17 \%$ from 1881 to 1900 , and $19 \%$ from 1901 to 1923 . We calculated a window glass mean date of 1864 for the total window assemblage.

\section{DISCUSSION}

\section{Dating the Construction of the Swaggerty Blockhouse}

The ceramic assemblage provided a mean date of 1852 whereas the window glass assemblage provided a mean date of 1864 . Although a mean date could not be calculated for the nail assemblage, the majority of nails recovered $(75 \%)$ were manufactured in the period 1830 to 1890 . The nails, window glass, and ceramics from the archaeological collection place the Swaggerty Blockhouse construction and use between 1852 and 1864. With the exception of a few ceramic sherds, we found little evidence in the archaeological assemblage to indicate construction, possible occupation, or use of the site in the late 1700s as documented in the historical record. The few sherds from ceramics known to be manufactured in the late $1700 \mathrm{~s}$ at most indicate use of these objects at the site, and not occupation of the site at that time (Ellerbusch et al. 2005).

These findings were corroborated by the results from our dendrochronological analyses that demonstrated harvesting of oaks between 1859 and 1860 to be used in the construction of the Swaggerty Blockhouse and likely completion of the structure by 1860 or 1861 . These oak logs provided a high-quality site chronology extending from 1673 to 1859 that can now be used as a new reference chronology for dating other historic structures in the region. Furthermore, our study provides strong support for dates derived for historic sites (i.e. post-1600) using artifact assemblages recovered from the immediate area when dendrochronological methods are not possible or feasible. The Swaggerty Blockhouse, believed to have been built in 1787 , consists of trees that were harvested between 1859 and 1860 , thus placing its time of construction during the period in which the farm was owned and operated by Jacob Stephens from 1850 to 1879 .

\section{Blockhouse or Small Cantilever Barn?}

Careful inspection of the Swaggerty Blockhouse also called into question its authenticity as a frontier blockhouse. Existing cantilever barns in eastern Tennessee show key architectural characteristics that help in their identification (Moffett and Wodehouse 1993). First, the eastern Tennessee cantilever barn is exclusively constructed with the lower floor (i.e. the second level) built with round or hewn logs and an upper floor (i.e. the third level) built with framed walls. The third level of the Swaggerty Blockhouse has heavy framing timbers joined with mortise and tenon, suggestive of a cantilever barn. Second, the walls of the upper floor of cantilever barns are covered with clapboard siding produced with the use of a mechanized circular saw. The Swaggerty Blockhouse has upper loft walls covered with lapped horizontal clapboard siding. Third, portholes used for placement of weapons are a visible characteristic in walls of existing blockhouses and forts. The Swaggerty Blockhouse has none. Lastly, the degree of depth of the cantilevered upper floor of a barn can be distinguished from a blockhouse configuration. The cantilevers on barns may be up to 20 feet $(6.1 \mathrm{~m})$ over the lower level, whereas blockhouses required only a small degree of a cantilevered upper floor (a maximum of two feet) to ensure a firing position with a clear field of fire. As a result, only a small degree of a cantilevered upper floor was necessary in a blockhouse. The amount of cantilever displayed on the Swaggerty Blockhouse is more suggestive of a cantilever barn than a blockhouse. In summary, the Swaggerty Blockhouse displays all the characteristics that distinguish it as a cantilever barn and not a fortified frontier blockhouse. Interestingly, cantilevered barns make their appearance in eastern Tennessee ca. 1860 (Moffett and Wodehouse 1993).

\section{From Blockhouse to Hog House}

Sometime after buying the property from James Swaggerty in 1850, Jacob Stephens focused on hog production. In the 1860 census, Stephens is listed as having 75 swine that comprised $91 \%$ of his livestock total, valued at $\$ 1060$, and 800 
bushels of Indian corn that comprised $70 \%$ of his grain total, valued at $\$ 484$ (U.S. Census Office 1860). By the 1870 census, Stephens is listed as having 30 swine, making up $33 \%$ of his total livestock, and 400 bushels of Indian corn, making up $62 \%$ of his total crop production (U.S. Census Office 1870). The archival data gathered show the high level of swine and corn production Stephens maintained, clearly suggesting that his farming focused on swine and corn production. The presence of swine bones located in or on top of a very thick ash layer on the north and northwest side of the structure further corroborates usage of the area for processing and butchering hogs. Based on multiple lines of evidence (tree-ring dating, ceramics, nails, window glass, and historical documents), the structure known as the "Swaggerty Blockhouse of 1787" should instead be identified as the "Stephens Hog Barn of 1860."

\section{ACKNOWLEDGMENTS}

Daniel Lewis, Ola Johansson, Leah Manos, Bill Reding, and Caroline Mann deserve praise for their extensive help in the field and for their suggestions and observations in the laboratory. Will Fontanez helped re-draft Figure 2 for publication. We especially thank the Gillespie family for their dedication to the Swaggerty Blockhouse site and for granting us permission to carry out this research.

\section{REFERENCES CITED}

Bannister, B., 1962. The interpretation of tree-ring dates. American Antiquity 27:508-514.

Barlar, D. G., 2000. Temporal and spatial variation in annual growth of tulip-poplar (Liriodendron tulipifera L.) at Walker Branch Watershed, Tennessee M.S. thesis, University of Tennessee, Knoxville.

Benson, T., 1988. The Timber Frame Home: Design, Construction, Finishing. Taunton Press, Newtown, Connecticut.

Cook, E. R., 1983. Lilley Cornett Tract, Kentucky, White Oak Chronology, KY003R. IGBP Pages/World Data Center for Paleoclimatology. NOAA/NGDC Paleoclimatology Program, Boulder, Colorado. http://www.ncdc.noaa.gov/paleo/ treering.html (accessed 3 March 2007).

, 1985. A Time Series Analysis Approach to Tree-Ring Standardization. Ph.D. dissertation, University of Arizona, Tucson.

Dean, J. S., 1978. Tree-ring dating in archaeology. In Miscellaneous Collected Papers 19-24, edited by J. D.
Jennings, pp. 129-163. University of Utah Anthropological Papers 99.

Druckenbrod, D. L., M. E. Mann, D. W. Stahle, M. K. Cleaveland, M. D. Therrell, and H. H. Shugart, 2003. Lateeighteenth-century precipitation reconstructions from James Madison's Montpelier plantation. Bulletin of the American Meteorological Society 84:57-71.

Duvick, D. N., 1981. Norris Dam State Park, Tennessee, White Oak Chronology, TN008. IGBP Pages/World Data Center for Paleoclimatology. NOAA/NGDC Paleoclimatology Program, Boulder, Colorado. http://www.ncdc.noaa.gov/paleo/ treering.html (accessed 3 March 2007).

Ellerbusch, E. C., B. A. Creswell, and G. J. Gomez, 2005. Archaeological Inquiry at Rocky Mount (40SL386), an Historic Frontier Homestead in Piney Flats, Sullivan County, Tennessee. Final Report prepared for the Rocky Mount Museum and the Center for Appalachian Studies and Services.

Euler, R. C., G. J. Gumerman, T. N. V. Karlstrom, J. S. Dean, and R. H. Hevly, 1979. The Colorado Plateaus: Cultural dynamics and palaeoenvironment. Science 205:1089-1101.

Faulkner, C. H., 1984. An Archaeological and Historical Study of the James White Second Home Site. University of Tennessee, Department of Anthropology, Report of Investigations No. 28.

Glassie, H., 1963. The Appalachian log cabin. Mountain Life and Work 39:5-14.

Grissino-Mayer, H. D., 2001. Evaluating crossdating accuracy: A manual and tutorial for the computer program COFECHA. Tree-Ring Research 57:205-221.

Grissino-Mayer, H. D., and S. L. van de Gevel, 2007. Tell-tale trees: The historical dendroarchaeology of log structures at the Rocky Mount site, Piney Flats, Tennessee. Historical Archaeology 41:30-47.

Grissino-Mayer, H. D., and J. P. Henderson, 2006. The historical dendroarchaeology of the Hoskins House, Tannenbaum Historic Park, Greensboro, North Carolina. Final Report, Tannenbaum Historic Park and the Guilford Battleground Company, Greensboro, North Carolina. 38 pp.

Hester, T. R., R. F. Heizer, and J. A. Graham, 1975. Field Methods in Archaeology. Mayfield Publishing Company, Palo Alto, California.

Hilliard, J. E., and K. J. Thomson, 2000. Tree-ring dating and archeology of an Ozark pioneer period farmstead: The McGarrah-Reed Site (3WA841). The Arkansas Archeologist 39:57-68.

Holmes, R. L., 1983. Computer-assisted quality control in treering dating and measurement. Tree-Ring Bulletin 43:69-78.

Houston, S. K., 1984. Greene County, Tennessee, Guardians and Orphans Court Records, 1783-1870, and 1830 Tax List. Southern Historical Press, Easley, South Carolina.

Jordan, T. G., 1985. American Log Buildings: A Folk Architecture. University of North Carolina Press, Chapel Hill, North Carolina.

Jurney, D. H., 1986. A newly discovered east Texas log courthouse. Bulletin of the Texas Archeological Society 55: 53-60.

Kniffen, F., 1969. On corner-timbering. Pioneer America 1:1-8. 
Kniffen, F. B., 1990. Cultural Diffusion and Landscapes. Department of Geography and Anthropology, Louisiana State University, Baton Rouge, Louisiana.

Kniffen, F., and H. Glassie, 1966. Building in wood in the eastern United States: A time-place perspective. Geographical Review 56:40-66.

Lafon, C. W., 2004. Stand dynamics of a yellow-poplar (Liriodendron tulipifera L.) forest in the Appalachian Mountains, Virginia, USA. Dendrochronologia 22:43-52.

Miller, G. L., 1980. Classification and economic scaling of nineteenth century ceramics. Historical Archaeology 14:1-40.

Moffett, M., and L. Wodehouse, 1993. East Tennessee Cantilever Barns. University of Tennessee Press, Knoxville.

Moir, R. W., 1987. Socioeconomic and chronometric patterning of window glass. In Historic Buildings, Material Culture, and People of the Prairie Margin, edited by D. H. Jurney, and R. W. Moir, pp. 73-81. Richland Technical Series Volume V. Archaeology Research Program, Institute for the Study of Earth and Man, Southern Methodist University, Dallas, Texas.

Nash, S. E., 1999. Time, Trees, and Prehistory: Tree-Ring Dating and the Development of North American Archaeology, 1914-1950. University of Utah Press, Salt Lake City.

National Register of Historic Places, 2007. Tennessee - Cocke County. http://www.nationalregisterofhistoricplaces.com/TN/ Cocke/state.html (accessed 3 March 2007).

Noel-Hume, I. N., 1969. A Guide to Artifacts of Colonial America. Alfred A. Knopf, New York.

Orvis, K. H., and H. D. Grissino-Mayer, 2002. Standardizing the reporting of abrasive papers used to surface tree-ring samples. Tree-Ring Research 58:47-50.

Polhemus, R., 1977. Archaeological investigation of the Tellico Blockhouse Site. University of Tennessee, Department of Anthropology, Report of Investigations No. 26. TVA Reports in Anthropology No. 16.
Quimby, I. M. G., Editor, 1973. Ceramics in America. University Press of Virginia, Charlottesville.

South, S., 1977. Method and Theory in Historical Archaeology. Academic Press, New York.

Stahle, D. W., 1979. Tree-ring dating of historic buildings in Arkansas. Tree-Ring Bulletin 39:1-28.

Stahle, D. W., M. K. Cleaveland, D. B. Blanton, M. D. Therrell, and D. A. Gay, 1998. The Lost Colony and Jamestown droughts. Science 280:564-567.

Stine, L. F., 2005. Results of 2004 archaeological testing at Tannenbaum State Park, 31GF413, Greensboro, North Carolina. Report prepared for the City of Greensboro's Tannenbaum Historic Park, the Guilford Battleground Company, and the Tannenbaum-Sternberger Foundation, $50 \mathrm{pp}$.

Stokes, M. A., and T. L. Smiley, 1968. An Introduction to TreeRing Dating. University of Chicago Press, Chicago, Illinois.

U.S. Census Office, 1860. Eighth Census of the United States in 1860: Head of Household. Government Printing Office, Washington D.C.

U.S. Census Office, 1870. Ninth Census of the United States in 1870: Head of Household. Government Printing Office, Washington D.C.

Wells, T., 1998. Nail chronology: The use of technologically derived features. Historical Archaeology 32:78-99.

Wight, G. D., and H. D. Grissino-Mayer, 2004. Dendrochronological dating of an Antebellum Period house, Forsyth County, Georgia, U.S.A. Tree-Ring Research 60:91-99.

Young, A. L., 1994. Nailing down the pattern. Tennessee Anthropologist 19:1-21.

Received 3 April 2007; accepted 18 July 2008. 